\title{
Polydactyly and the Maya
}

A Review and a Case from the Site of Peligroso, Upper Macal River Valley, Belize

Wrobel, Gabriel D.; Helmke, Christophe; Nash, Lenna; Awe, Jaime J.

Published in:

Ancient Mesoamerica

DOI:

$10.1017 / \mathrm{S} 1368980008002541$

Publication date:

2012

Document version

Publisher's PDF, also known as Version of record

Citation for published version (APA):

Wrobel, G. D., Helmke, C., Nash, L., \& Awe, J. J. (2012). Polydactyly and the Maya: A Review and a Case from the Site of Peligroso, Upper Macal River Valley, Belize. Ancient Mesoamerica, 23(1), 131-142.

https://doi.org/10.1017/S1368980008002541 


\title{
POLYDACTYLY AND THE MAYA: A REVIEW AND A CASE FROM THE SITE OF PELIGROSO, UPPER MACAL RIVER VALLEY, BELIZE
}

\author{
Gabriel D. Wrobel, ${ }^{\mathrm{a}}$ Christophe Helmke, ${ }^{\mathrm{b}}$ Lenna Nash, ${ }^{\mathrm{c}}$ and Jaime J. Awe ${ }^{\mathrm{d}}$ \\ aDepartment of Anthropology, Michigan State University, 355 Baker Hall, East Lansing, MI 48824 \\ bepartment of American Indian Languages and Cultures Institute of Cross-cultural and Regional Studies, University of Copenhagen, \\ DK-2300 Copenhagen S, Denmark \\ 'Illinois State Archaeological Survey, Prairie Research Institute, University of Illinois at Urbana-Champaign, American Bottom Field \\ Station, Wood River, Illinois 62095 \\ dinstitute of Archaeology, National Institute of Culture and History, Belmopan, Belize
}

\begin{abstract}
A single right fifth metatarsal found in Tomb 1 at Peligroso, Belize exhibited a small deformity in the form of a small (7 mm) accessory digit emanating from the plantar surface at mid-shaft. This Type A postaxial polydactyly is the first archaeological example of polydactyly reported for Mesoamerica. Polydactyly is one of the more commonly reported morphological anomalies and thus its appearance in Maya populations would have been prevalent enough to demand explanation. A review of related terminology in pertinent Amerindian languages is presented as a means of exploring the manners in which digits and the human body are conceptualized. Maya iconographic representations of polydactyly at Palenque have parallels to other Mesoamerican renderings of supernumerary digits used to identify divinities and deified ancestors. However, the Peligroso mortuary context comprised disarticulated and commingled bones, suggesting that the individual did not have a distinctive social role related to the presence of an extra digit.
\end{abstract}

Polydactyly is a developmental defect of the hands or feet manifested in a variety of ways that range from a small skin tag without bones (a pedunculated postminimus) to a complete duplication of a digit. At present, very few skeletal examples are known from archaeological contexts. The vast majority of these come from the American Southwest, where cases have been reported from the sites of Chaco Canyon, New Mexico (Barnes 1994); Pueblo de Las Humanas, Gran Quivira National Monument, New Mexico (Reed 1981:114-115); Sand Canyon Pueblo, Colorado (Kuckelman and Martin 2007); Schoolhouse Point Mound, Arizona (Regan et al. 1996:810); and Tapia del Cerrito and Nuvakwewtaqa (Chavez Pass Ruin), Arizona (Case et al. 2006). Additional archaeological cases are documented from the Iron Age site of Simbusenga, Zambia (Murphy 1999), from the Moe Kau a Ho'oilo site in Hawai'i (Han et al. 1986), and most recently from the Inca site of Qotakalli in Cuzco, Peru (Valerie Andrushko, personal communication 2010).

The purpose of this paper is to describe a case of polydactyly that was recently discovered in a tomb from the Upper Macal River Valley of Belize. This case is significant because it is the first prehistoric skeletal example of polydactyly documented in Mesoamerica. In addition, we discuss two other important aspects of polydactyly as it relates to general themes within Mesoamerican archaeology. First, because the manifestation of polydactyly is primarily under genetic control, documentation of its prevalence can theoretically inform researchers about relatedness

E-mail correspondence to: wrobelg@msu.edu between affected individuals and allow them, in some cases, to trace patterns of inheritance within and between groups. We review the medical literature to assess the utility of this approach in bioarchaeological studies. Second, it has been argued that in some cultures individuals displaying extra digits at birth might have received differential treatment in life, taking on specific social roles on the basis of religious interpretations of their unusual physiology. For this reason, we review iconographic representations of polydactyly by the Maya and other Mesoamerican groups, and discuss the possible social significance of this variation.

\section{A NEW CASE OF POLYDACTYLY}

In 2003 and 2004, the Belize Valley Archaeological Reconnaissance (BVAR) Project conducted salvage excavations across $17 \mathrm{~km}^{2}$ in the Upper Macal River Valley (Figures 1 and 2) prior to the construction of the Chalillo Dam, which now has inundated numerous prehistoric Maya sites (Awe et al. 2005) (Figure 2). Survey of this previously unexplored region identified the architectural remains of 334 masonry buildings ranging from simple isolated structures to multiple-plaza complexes. On the basis of the relatively uniform distribution of sites, their location along the Macal River system, and their proximity to several other large centers including Caledonia, Maria Camp, Mountain Cow, and the largest site in Belize, Caracol, it is likely they were integrated within a complex political and economic regional network. Unfortunately, time and budget constraints limited excavations to structures within nine sites, and these excavations 


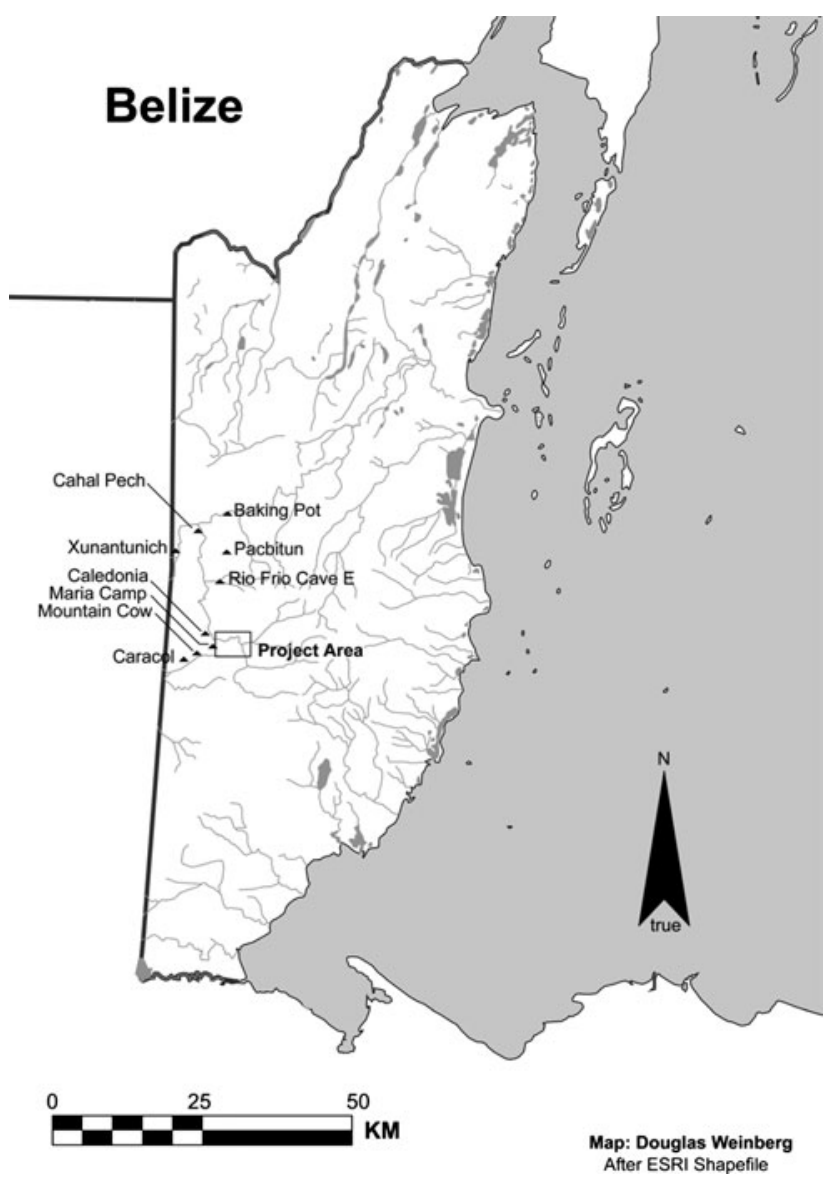

Figure 1. Map of Belize showing the location of sites mentioned in the text. Map aligned to UTM grid north. Map by Douglas Weinberg.

generally focused on elite contexts only. Specifically, the project targeted eastern structures, which traditionally functioned as ancestral shrines and contain sealed contexts such as tombs, crypts, and caches (Becker 1971, 1999; Chase and Chase 1994; Welsh 1988).

The evidence for polydactyly in this study consists of a single right fifth metatarsal found within Tomb 1 of Structure 84 at the site of Peligroso (Figure 3). Within the tomb was the primary seated burial of a juvenile (Burial 7) and a mass of mostly commingled human skeletal remains (Burial 8) from which the affected metatarsal originated (Figure 4). In addition, the tomb contained a rich assemblage of artifacts that included 17 ceramic vessels, one jadeite bead, one small perforated slate disk, five obsidian blades, a few fragments of worked bone including a carved bone pendant decorated with a face, a bone whistle, four secondary chert flakes, and seven worked shell ornaments (Awe et al. 2005:41) (Figure 5). The form and Type-Variety of the vessels suggest occupation during the transitional period from the Early Classic to the Late Classic period, corresponding to the Tiger Run ceramic complex (A.D. 550-650) (see Gifford 1976:191-193).

Burial 8 was photographed and mapped in situ (Figure 4). The salvage nature of the project necessitated that the burial be blocklifted in segments. Bones were then extracted from the matrix in a controlled laboratory setting. Because of this excavation method, the relative positions of elements within the tomb remain difficult to ascertain. Thus, it is unknown whether the affected metatarsal was part of a partially articulated individual or was among the pile of fully disarticulated and commingled remains. However, Burial 8 does demonstrate the sequential use of the tomb through time, whereby skeletal remains were apparently repeatedly swept aside to allow for the interment of additional individuals (Awe et al. 2005:41; see also Chase 1994; Healy et al. 1998). An inventory of the Burial 8 teeth supports this inference, as it includes the incomplete remains of a minimum of three individuals. Furthermore, the incomplete dentitions of at least two more individuals were found within one of the tomb's many vessels. All bones appear to belong to adults. No deciduous teeth were present and all dentitions showed varying stages of attrition consistent with adults. Unfortunately, the sexing of individuals was not possible, although one mandibular fragment exhibited strong masseter muscle attachments suggesting a male.

During the initial lab processing and inventorying of the human remains from Burial 8, a single right metatarsal was noted to have a growth emanating from its plantar surface (Figure 6). The protuberance extends approximately $7 \mathrm{~mm}$ and has a rounded end with what appears to be a small foramen. An X-ray of the specimen (Figure 7) reveals that the foramen does not extend further into the protuberance, which would be expected if this were a growth resulting from infection, such as osteomyelitis. Furthermore there is no evidence on the bone of any periosteal reaction, such as swelling or porosity, nor is there any evidence of trauma to the bone. The smooth and rounded distal end of the protuberance is consistent with an articular surface and might have supported phalanges. Alternatively, the slight mushroom-like appearance suggests the cap might have been cartilaginous. Because of this morphology, we do not rule out the possibility that this is a solitary osteochondroma, which is a benign bone tumor formed during development (and thus not a true neoplasm) (Murphey et al. 2000). Osteochondromas may be difficult to distinguish from polydactylys because both are composed of cortical and cancellous bone protruding from and continuous with the underlying bone. However, osteochondromas rarely affect the bones of the hands and feet (only 10\% of clinical cases) (Murphey et al. 2000:1410). In addition, osteochondromas form from growth plates-as a result they are usually located on the metaphyses and proliferate diagonally to the long axis and outward from the neighboring joint. The Peligroso example originates from the diaphysis and extends perpendicularly, which is consistent with many forms of polydactyly.

Cases of polydactyly are classified on the basis of their position on the hands or feet. Because this example of polydactyly appears on the lateral side (i.e., fifth digit), it is called "postaxial." Preaxial polydactyly affects the thumb or big toe, and central polydactyly, which is extremely rare, affects the intermediate digits. Sub-classifications of these main types are based on the extent and on the location of accessory digits. Postaxial polydactyly can be subdivided into Types A and B. The Type A form is generally differentiated from Type B by the presence of skeletal elements, and Type A anomalies are further differentiated by the degree to which the extra digit is expressed. Figure 8 shows a range of branching patterns based on documented cases. The Peligroso specimen most resembles the "T-shaped metatarsal in which the distal articular end is in roughly anatomical position, while a branch with its own articular end projects laterally from the midshaft of the fifth metatarsal" (Case et al. 2006:225) (Figure 8d). Unilateral expression is slightly more common than bilateral expression (Castilla et al. 


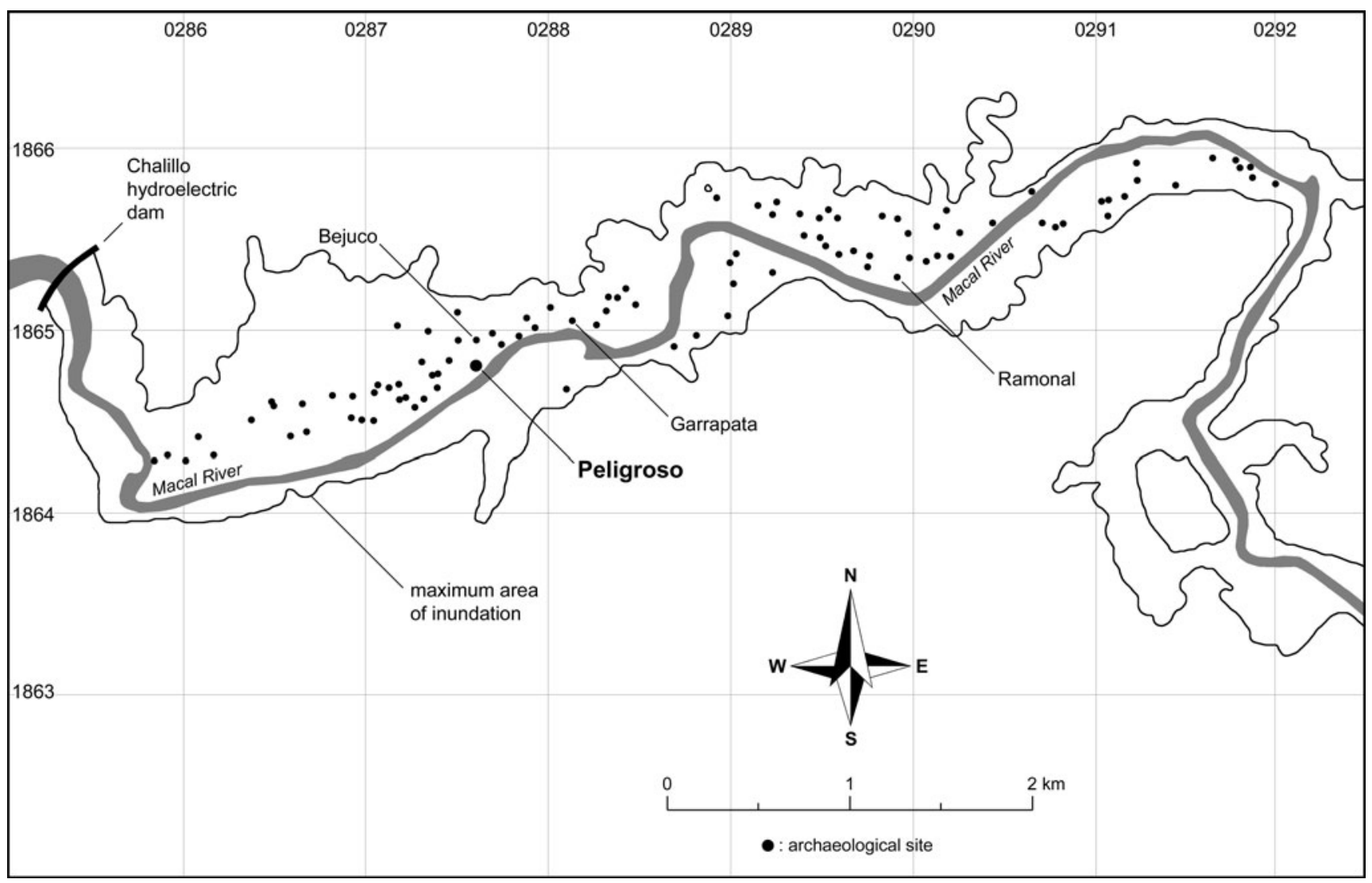

Figure 2. Map of the Chalillo area in which the Belize Valley Archaeological Reconnaissance Project conducted salvage excavations, showing the location of archaeological sites identified and investigated, as well as the maximum area of inundation brought on by the construction of hydroelectric dam. Map aligned to UTM grid north. Map by Christophe Helmke and Douglas Weinberg.

1973), but the antimere could not be positively identified among the commingled remains.

\section{THE GENETIC SIGNIFICANCE OF POLYDACTYLY}

In theory, one important aspect of polydactyly for bioarchaeological studies is that it appears to be epigenetic in nature and thus is generally heritable. Epigenetic traits are ones whose expressions are influenced by both genetic and non-genetic (environmental) factors. Forensic and bioarchaeological studies often utilize rare discrete morphologies in the form of epigenetic traits when seeking to identify genetic relationships between individuals found in proximity to one another or within a common context such as a cemetery or tomb (Hauser and De Stefano 1989; Lane and Sublett 1972). For

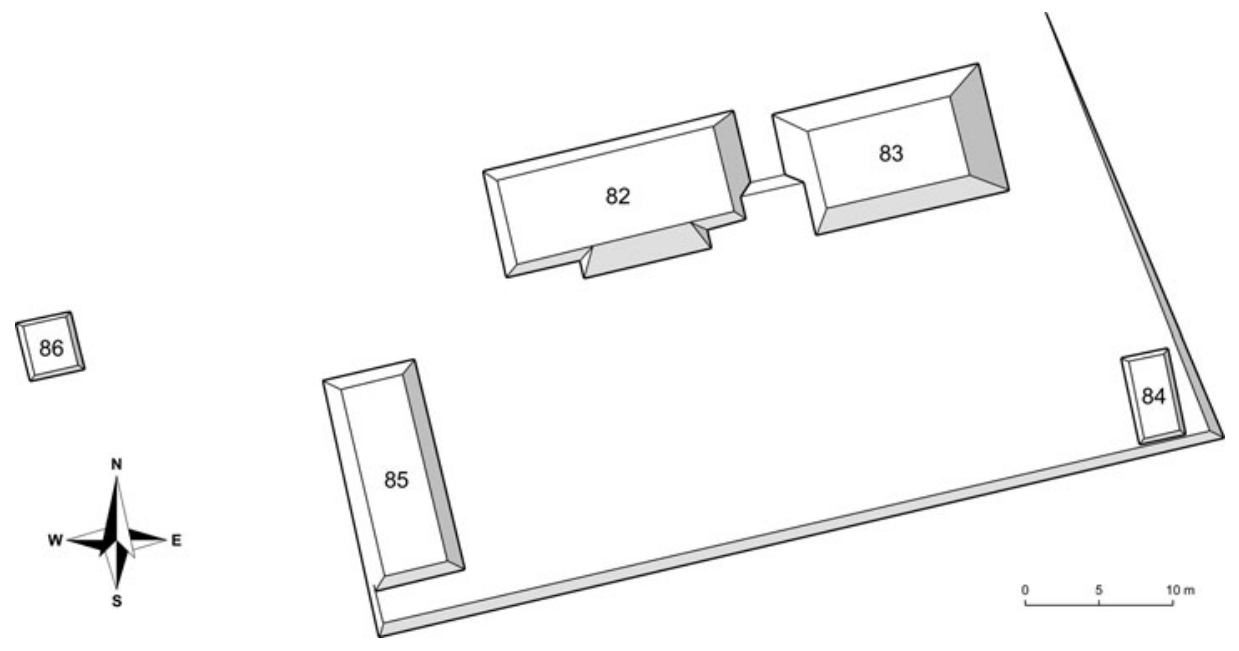

Figure 3. Plan of the site of Peligroso. Plan aligned to magnetic north. Plan by Christophe Helmke (after original by Nazario Puc [Awe et al. 2005:Figure 21]). 


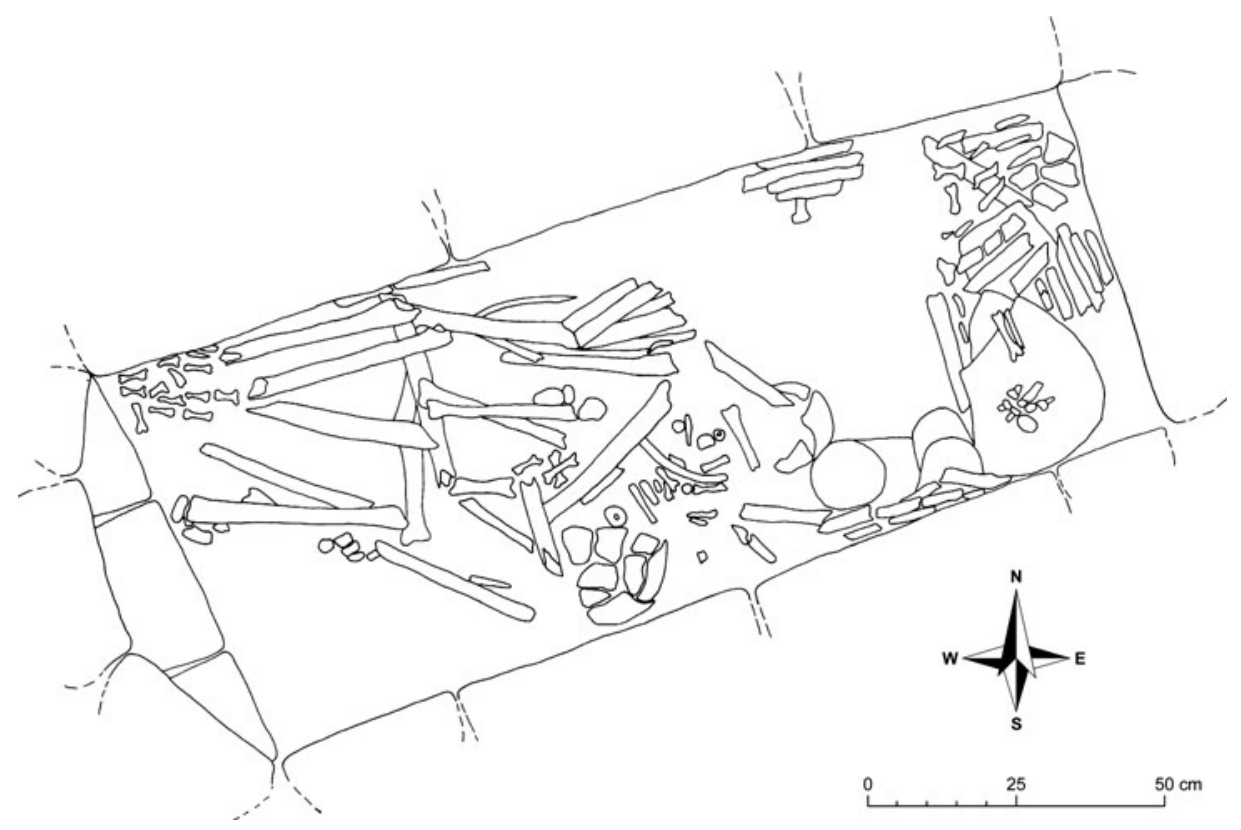

Figure 4. Plan of Tomb 1, Burial 8 (Level 2, Structure 84) at the site of Peligroso. Plan aligned to magnetic north. Plan by Nazario Puc (Awe et al. 2005:Figure 23).

instance, in a Mesoamerican example Christensen (1998) argued for relatedness among individuals within a Zapotec tomb primarily on the basis of the presence of metopic sutures. However, the specific morphological manifestation in an individual carrying a genetic code for an epigenetic trait can vary as a result of environmental influences or the differential cumulative effects of several genes affecting the trait, and thus the genotype-phenotype relationship is often unpredictable (Hauser and De Stefano 1989). Our discussion here focuses on the reliability and practicality of using polydactyly in such a manner to explore the nature of its inheritance patterns. Many aspects of these observable patterns, such as their rarity and their propensity to appear within a particular family grouping, are also important to understand in a bioarchaeological context because they would no doubt influence cultural interpretations of polydactyly.

Using data from both pedigree studies and genetics, researchers have expended a great deal of effort attempting to determine the exact modes of inheritance and transmission of polydactyly. In general, most forms of polydactyly tend to show generally high heritability; that is, affected individuals are more likely than not to have affected relatives (Castilla et al. 1996:298; Feitosa et al. 1998:471). However, numerous pedigree studies tracing the occurrence of polydactylys within families of affected individuals have generally failed to identify any predictable patterns of transmission and inheritance (Radhakrishna et al. 1993; Venn-Watson 1976; Walker 1961; Woolf and Woolf 1970). One reason for this unpredictability is that there appear to be many different patterns of transmission. For instance, the different forms of polydactyly, such as the preaxial and postaxial types or those affecting the hands and feet, seem to be inherited independently from one another, even in the rare cases in which they appear together in the same individual (Feitosa et al. 1998: 469; Woolf and Woolf 1970:80). However, even studies focusing only on specific polydactyly types still fail to predict the occurrence of the anomaly within affected families (Castilla et al. 1973; Phelps and Grogan 1985; Radhakrishna et al. 1993; Walker 1961).
Another reason for the lack of predictability relates to the nature of the underlying genetic control of polydactyly. In general, polydactylys, like most other epigenetic traits, are polygenic; that is, their expression is based on the combined influence of several genes. Postaxial forms, for instance, have been attributed to the cumulative effect of several autosomal dominant genes exhibiting low penetrance and variable expressivity (Castilla et al. 1973). Specifically, new evidence from molecular genetics has identified the culprits as a series of mutations affecting genes that regulate limb development (Maas and Fallon 2005; Talamillo et al. 2005). The identification of specific controlling genes explains the high heritability, because individuals within the same family will carry much of the same genetic information. However, the variability in the presence, as well as in the severity of expression, of polydactyly within families results from the fact that these genes are almost never phenotypically expressed, and when they are the expression is "incomplete." This is demonstrated by the fact that cases of polydactyly in the same families can show considerable morphological variation, can skip generations, and can be seen in distant relatives, suggesting that the genes are widespread even in families in which few people express the deformity. Thus, unfortunately for physical anthropologists, most people who carry the genes won't have polydactyly, and those who do will probably express dissimilar morphologies.

Further confounding any study that seeks to identify genetic relationships between individuals, some cases of polydactyly do not seem to be related to the complex epigenetic inheritance mechanism discussed above. For instance, some population-specific patterns may be attributable to environmental causes, though at present these examples are limited only to preaxial polydactyly, which occasionally has a greater occurrence among the offspring of mothers with diabetes (Martínez-Frías et al. 1992). In other instances, polydactyly (usually postaxial) may arise in association with other symptoms as part of a syndrome (see Christensen et al. 1981:Table 1; Ruby and Goldberg 1976:371-372). Postaxial 


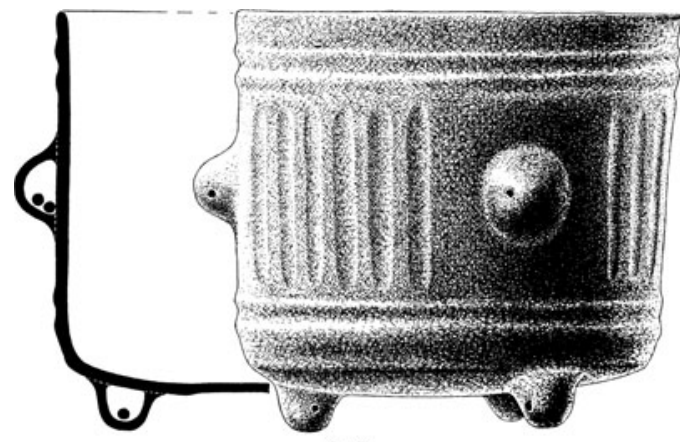

(a)

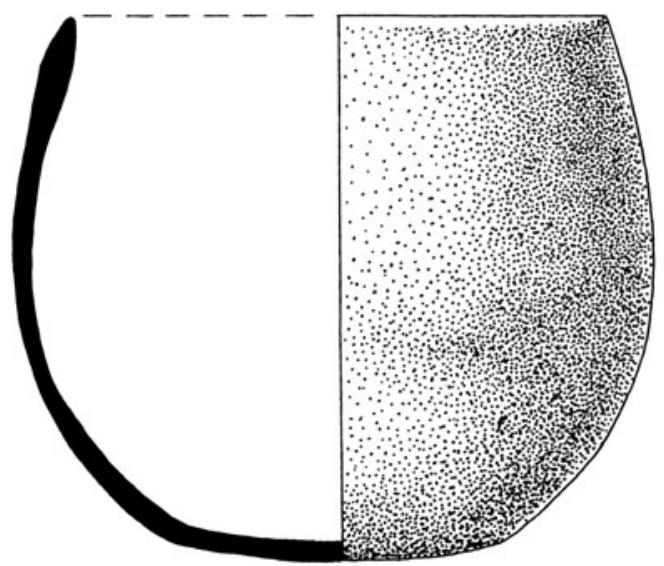

(b)

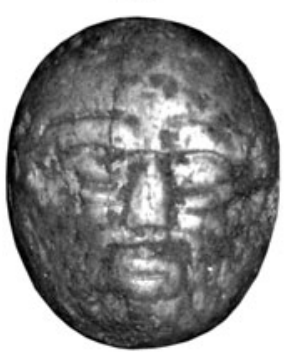

(c)

Figure 5. A selection of artifacts recovered from Tomb 1 at the site of Peligroso. (a) Tripod vase related to Silkgrass fluted type (maximum diameter $16 \mathrm{~cm}$ ). (b) Macal Orange-red hemispherical bowl (maximum diameter $14 \mathrm{~cm}$ ). (c) Carved bone pendant (maximum width $6 \mathrm{~cm}$ ). Drawings by Juan Ramirez. Photograph by Douglas Weinberg.

polydactyly in particular has been associated with autosomal recessively inherited syndromes, specifically several of the trisomy conditions in which the individual carries a third copy of a chromosome. Finally, in some geographic areas, polydactyly has a low enough familial incidence $(10 \%$ or less) to indicate that those cases may be sporadic rather than inherited (Watanabe et al. 1992:869). This wide assortment of underlying causes also seems to be partially responsible for much of the variability in patterns of expression. For instance Castilla and colleagues (1973) found among postaxial polydactylys that Type B was preferentially expressed on hands and on the left side with no difference between sexes, while Type A showed a higher incidence among males and on feet with no difference between sides.

Like other epigenetic traits, polydactyly has the potential to inform us about biological relationships between individuals and

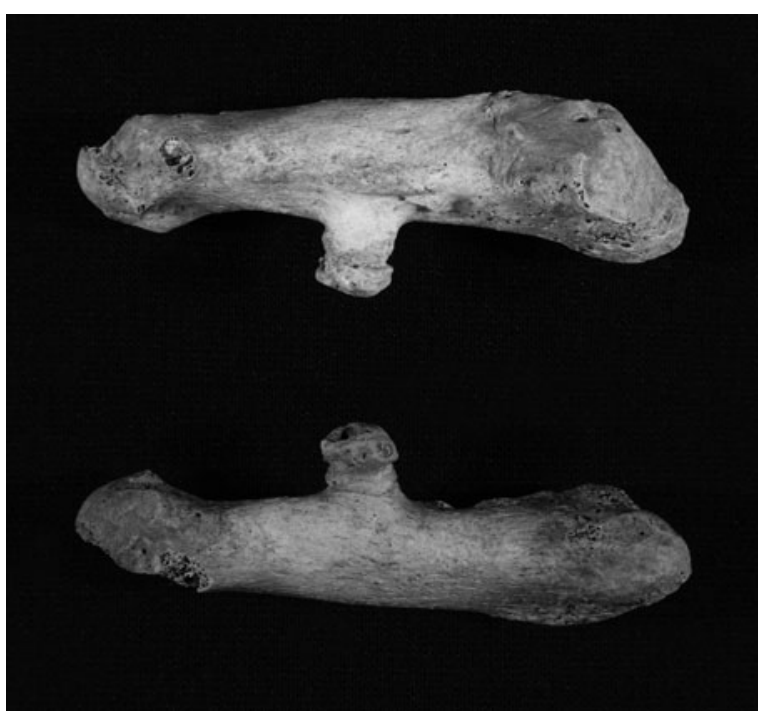

Figure 6. Two views of the right fifth metatarsal with a growth emanating from its plantar surface; Burial 8, Peligroso. (a) Medial view, and, (b) lateral view. Photographs by Brooke White.

groups. In Maya archaeological contexts, these data are of particular interest in interpreting the relationships of individuals interred together within tombs or other burial groupings, or within specific socioeconomic groups within or across sites and regions. Despite the problems discussed above, we can hypothetically acknowledge that in most instances polydactyly displayed by multiple individuals within a bounded context may indicate genetic ties amongst them. Large-scale studies from hospitals show that most cases are not related to specific syndromes or environmental causes (Bingle and Niswander 1975:93). In practice, though, this methodology is extremely limited, because it relies only on the expression of rare traits to identify these relationships. As discussed above, most individuals carrying the genes for polydactyly will not express them; therefore, one cannot conclude that individuals who do not display the phenotype are unrelated to those who do. For this reason, studies utilizing

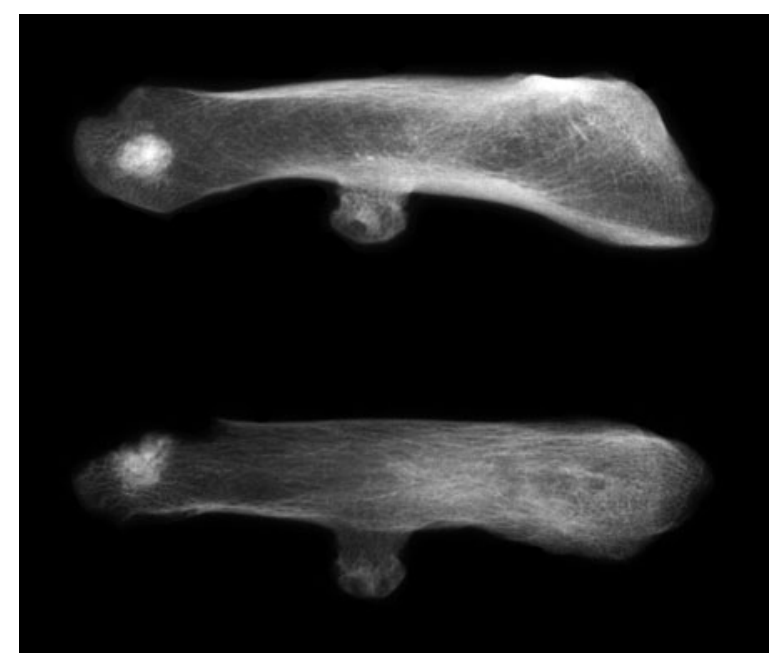

Figure 7. X-ray of the right fifth metatarsal; Burial 8, Peligroso. X-ray photography conducted by the University of Mississippi Student Health Services. 

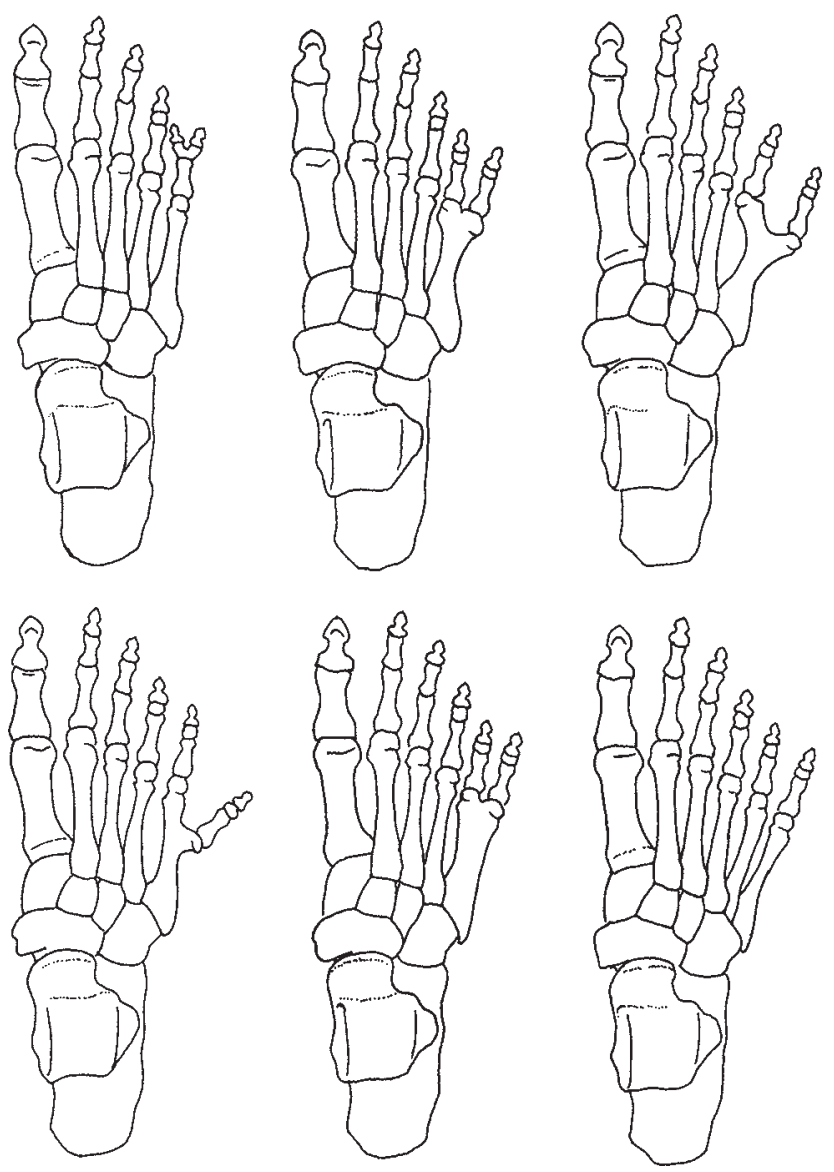

Figure 8. A range of branching patterns of polydactyly of the feet based on documented examples. Adapted from Case et al. (2006:Figure 4). The Peligroso case matches the example on the lower left.

epigenetic traits generally include multiple hereditary traits, because the expression of any single trait is highly unpredictable (Hauser and De Stefano 1989). From a cultural perspective, patterns of affectedness within a community might have been difficult to assess by groups like the ancient Maya. Pedigree studies show that although polydactyly does tend to run in families and that most biologically related individuals are carriers, the rarely occuring individuals that evidence genotypic expression of polydactyly typically would have been distantly related or separated by several generations. In some cases these genetic relationships between individuals might not have been deemed of sufficient cultural significance to be recorded, as can be suggested on the basis of kinship terms not represented in the Classic Maya written corpus (see Stuart 1997). All of these factors might have hindered the identification of polydactyly as an inherited trait, further marking an affected individual as distinctive.

\section{THE CULTURAL SIGNIFICANCE OF POLYDACTYLY IN THE AMERICAS}

Because polydactyly is such a highly distinctive, clearly visible, and relatively rare phenomenon, it is understandable that many groups have assigned it special cultural significance. In the Americas, rock art depictions of hands and feet with extra digits have been reported from La Rioja, Argentina (Castilla et al. 1973:Figure 1),
Chihuahua, Mexico (Jackson 1938), and the United States, especially in the Southwest (see Case et al. [2006] for a review). Several skeletons displaying polydactyly have been found in archaeological contexts in the Southwest, which help to further illuminate the significance of such depictions. Recently, Case et al. (2006) reported a case of polydactyly from an infant at the Tapia del Cerrito site in Arizona. The grave was clay-lined, which is an unusual burial treatment, and suggests that polydactyly conferred a special status on affected individuals.

Depictions of divinities with six fingers and toes are also found infrequently in several of Mesoamerica's civilizations. An Early Classic (A.D. 300-500) "host figurine" from Teotihuacan displays polydactyly of the hands but not the feet (Ochoa Castillo and Sodi Miranda 2009:298, Number 108) (see Figure 9a), whereas two Late Classic (ca. A.D. 500-700) Zapotec ceramic effigy censers, or urns, represent deities with six fingers on each hand (Due 2007:23; Sellen 2007:159; von Schuler-Schömig 1970: 101-102) (Figure 9b and 9c). It is noteworthy that these examples involve a deified ancestral figure (in the Teotihuacan case) and a particular deity with an avian headdress (in the Zapotec examples), suggesting that polydactyly indeed served as a distinctive attribute, here perhaps serving as a particular trait, differentiating between humans and supernaturals, in much the same way that dwarfism was considered a supernatural quality among the ancient Maya (Houston 1992; Miller 1985; Prager 2001). It bears noting that we surmise that such conceptualizations found their initial impetus in the actual physical deformities of real individuals, which over time eventually developed into markers of extraordinary or supernatural status.

Language provides us with a great opportunity to explore how the human body functions as an idealized conceptual template, contrasting the anatomical and the social entity. This is particularly evident in the relationship between human anatomy and numerical systems (see Trumbull 1874), which has a bearing on our discussion of appendages and socio-cultural perceptions of the human body. Fingers aptly serve as the basis of terms for single digits, as in English, where digit is defined as both 'finger' and 'number below ten' and by extension means 'number' generally. Hands, in turn, naturally form units of five digits, as seen in several Amerindian languages, in which the word for 'hand' and corresponding terms for the number five are closely related. In Mesoamerica, this is nowhere clearer than in Nawatl, the language of the Aztec, where the words $m \bar{a}-k^{w} \bar{l}-l i$ 'five' and $m \bar{a}$-tlak-tli 'ten' are derived from the root $m \bar{a}(i)-t l$ 'hand' (see Karttunen 1983:130, $131,133){ }^{1}$

With hands as intrinsic units of five, these aptly serve as the computational bases for arithmetic systems, including decimal (base-10) with two hands, or even vigesimal (base-20) with both hands and feet. Vigesimal systems in the New World are exceedingly rare in general except in Mesoamerica, where such systems are so common that these help define the areal extent of the linguistic

\footnotetext{
${ }^{1}$ Similarly, in the related Yuta-Nawan language Yaqui, of the Sonoran desert of northwest Mexico and Arizona, 'hand' is mam and 'five' is mam-ni (Rodríguez Villegas 2009a), and in Navajo where 'five' is ashd $l a$,' including $l a$ ' 'hand' (see Trumbull 1874:64). In much the same way in Kiliwa of Baja California 'hand' is sal and 'five' is sal-chipam (Rodríguez Villegas 2009b). The same features can be traced to the Salishan languages of the Pacific Northwest where words for 'five' and 'ten,' although widely cognate, clearly contain the lexical suffix for 'hand' (Thompson 1979:731; for select Arctic languages see Trumbull [1874:43, 63-65, 69-72]).
} 


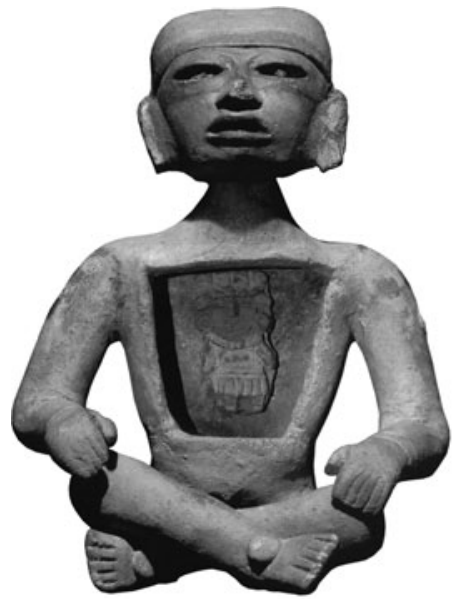

(a)

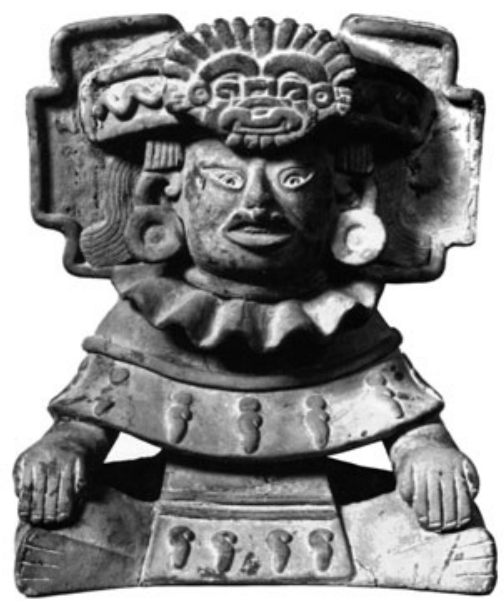

(b)

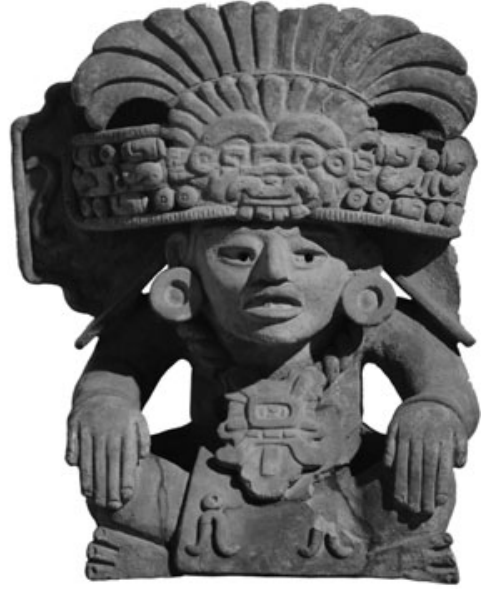

(c)

Figure 9. Examples of polydactyly in Mesoamerican iconography. (a) Early Classic (A.D. 300-500) ‘host figurine,' Teotihuacan (Museo Nacional de Antropología, Mexico, Number 10-223779; photograph by Mario Carrieri). (b) Late Classic (A.D. 500-700) Zapotec effigy with so-called Glyph C headdress, Tlatenango (adapted from von Schuler-Schömig [1970: Figure 145]). (c) Late Classic Zapotec ceramic effigy also with Glyph C headdress (National Museum, Denmark, Number 0.2052; photograph by Christophe Helmke).

and cultural area (Campbell 1979:957, 2004:333; Campbell et al. 1986:546-547; Haspelmath et al. 2005:530-533). ${ }^{2}$ A particularity of vigesimal systems is that four sets of digits are computed, including the hands and feet, amounting to a set of 20 digits for each person. Thus a complete set of digits and a person inherently form a coherent whole, which thereby fosters this essential equivalence. In much the same way that terms for "hands" and "five" are equivalent in specific languages, terms for "twenty" and "person" are inexorably intertwined in linguistic and cultural precepts, especially in Mesoamerican languages (Kaufman 2003:86-88, 1495-1496; Smith-Stark 1994:19, 20, 34).

Among the Maya of the Classic period (A.D. 250-900), the word winik, or its cognate winak, 'man'-not in the sense of a biological entity, but as a social 'person' or 'human'-was equivalent to the word for 'twenty' (see Houston et al. 2006:11-12, 15, 58-59), a feature documented in the glyphic script of the ancient Maya (Figure 10). Similarly, Tzotzil Maya ritual speeches can be closed by ta lahuneb kok, ta lahuneb hk'ob 'with my ten toes, with my ten fingers' (Laughlin 1975:67, 193) by which the human orator wholly invokes the supernatural. Thus a human, or a whole person, was inherently conceptualized as one with 20 digits, implying that the deficiency or extra-numeracy of digits ran counter to the definition of a human agent. As a consequence, it is clear that the terms winik $\sim$ winak '(hu)man, twenty' represent the norm, and that any deviance from this culturally-embedded ideal was deemed abnormal or at least out of the ordinary. It might be that such deviations were, and continue to be, a source of anxiety, prompting the counting of digits at birth to verify if someone can indeed be wholly qualified as winik (Houston et al. 2006:58-59; Vogt 1976:19-20).

${ }^{2}$ Outside of Mesoamerica, vigesimal systems in the New World are restricted to Cariban and Arawakan languages (e.g., Arawak, Carib, and Warao), of northeastern South America, or to Arctic languages such as Yup'ik and Chukchi (Haspelmath et al. 2005:530-533).

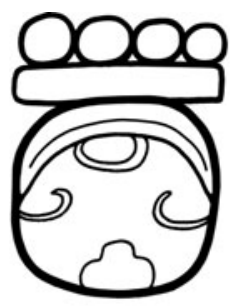

(a)

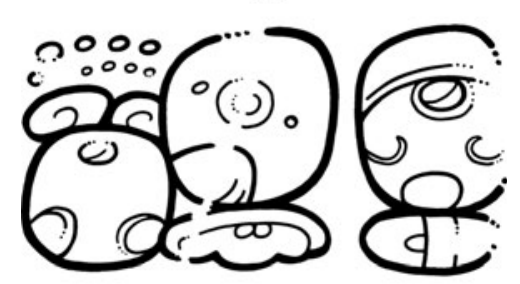

(b)

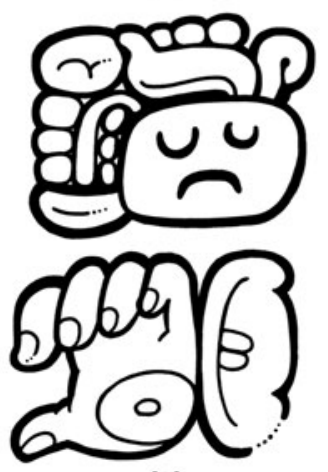

(c)

Figure 10. Examples of the terms winik winak in Classic Maya writing. (a) Winik 'month of twenty days' here in multiples of 9 (Tikal, Altar 5). (b) Winik 'person' used as part of the ethnonym k'uhul chatan winik 'godly-Chatan person' (Calakmul, Stela 51). (c) Winak in the quotation a-winak-e'n 'I am your man' (Piedras Negras, Panel 3). Drawings by Christophe Helmke. 


\section{POLYDACTYLY AT PALENQUE}

The best known representations of polydactyly in ancient Maya iconography are those from the site of Palenque in Chiapas, Mexico. In all, five images of what appear to be supernumerary digits on hands or feet have been documented on figurative panels and piers of three structures, as identified by Merle Greene Robertson and Linda Schele (Robertson et al. 1976; see also Schele and Miller 1986: 66, 74, Note 4; Schele and Freidel 1990:236). We will describe the images in order by dedicatory date of the buildings with which the examples are associated.

The first is House A, an audiencia structure, which formed the principal entrance to the royal palace at the site of Palenque. House A was probably completed about A.D. 668 during the reign of the renowned king K' inich Janaab Pakal I (A.D. 615-683) according to the dates associated with the sculpted stucco piers that adorn the exterior of the outer gallery of the building (Martin and Grube 2008:164-165; Stuart and Stuart 2008:147-184). The iconography of these piers are similar in composition: a standing regal male figure, holding a staff of office in one hand and an incense pouch in the other, framed by two seated figures depicting either ancestors or captives. On Pier D, the standing figure is shown holding the incense pouch in the right hand, which appears to exhibit six wellformed digits with fully-developed fingernails (Figure 11a and 11b) (Robertson et al. 1976:69). The matching left hand has weathered away and the feet are rendered in a stylized fashion, precluding comparisons of the right hand to the other appendages. Initially the standing figure was thought to depict K'inich Kan Bahlam II (A.D. 684-702), eldest son and successor to K'inich Janaab Pakal I (Martin and Grube 2008:168-170; Stuart and Stuart 2008: 185-215), but more recent interpretations favor the latter as the individual commemorated on the piers (Stuart and Stuart 2008:160).

The second set of polydactyly images is associated with the Temple of the Inscriptions - the mausoleum and devotional shrine to K'inich Janaab Pakal I. Although the exact date of completion of the Temple of the Inscriptions has not been adequately resolved, the structure was probably dedicated by K'inich Kan Bahlam II sometime between A.D. 688 and 690 (Guenter 2007:3-4; Stuart and Stuart 2008:171). The exterior of the temple, at the summit of the pyramidal structure, exhibits six decorated piers, of which the four central ones bore detailed figurative stucco panels. Again, the iconographic programs are shared between the piers, with each dominated by a richly-attired standing regal figure shown cradling an infant. The identity of the standing figures as nuclear relatives of K'inich Janaab Pakal I is confirmed by emblematic devices embedded into their headdresses (Guenter 2007:2-3; Stuart and Stuart 2008:169-170). Each infant figure exhibits a flaming or smoking celt embedded in its forehead and an elongated leg terminating in a monstrous serpent maw. These are diagnostic attributes of the youngest-born of Palenque's three patron gods, named in the inscriptions as the unen 'infant' manifestation of the deity K'awiil (also known as God K) (see Miller and Taube 1993:129-130, 147; Stuart and Stuart 2008:189-190). It is on Piers B and C that the feet of these supernatural entities exhibit polydactyly; the two lateral toes rendered with developed toenails but are shrunken in relation to the four central toes (Figure $11 \mathrm{c}$ and 11d). Initially these images were deemed to represent infant depictions of K'inich Kan Bahlam II (see Schele and Freidel 1990:236), but this no longer seems tenable because the figures clearly represent the diagnostic features of the supernatural entity Unen K'awiil (Stuart and Stuart 2008:170). Consequently these are either

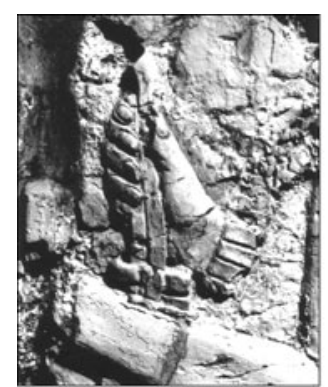

(a)

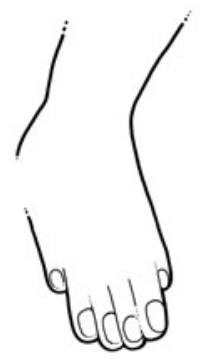

(c)

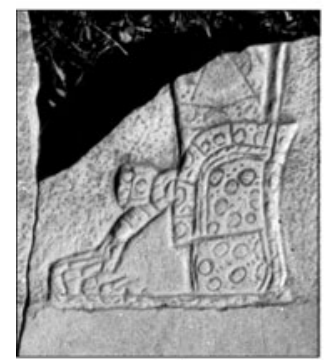

(e)

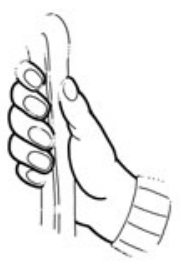

(b)

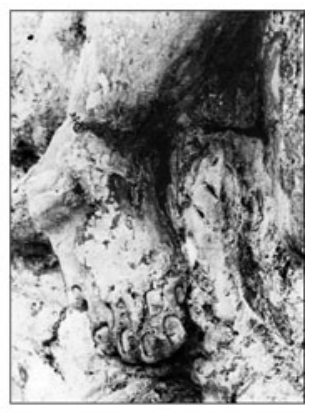

(d)

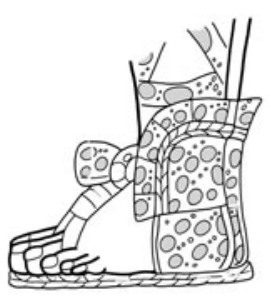

(f)
Figure 11. Polydactyly at Palenque, Mexico. Hand with six digits (House A, Pier D): (a) photograph by Merle Greene Robertson (1985:Figure 73); (b) drawing. Foot with six digits (Temple of the Inscriptions, Pier C): (c) drawing; (d) photograph by Merle Greene Robertson (Robertson et al. 1976:Figure 15). Foot with six digits (Temple of the Sun, North Jamb): (e) photograph by Merle Greene Robertson (1991:Figure 117); (f) drawing. All drawings by Christophe Helmke.

depictions of the supernatural entity itself or posthumous renditions of human figures (see Colas 2009).

The third set of examples are found on carved limestone panels of the Temple of the Sun which, along with the so-called Temples of the Cross and Foliated Cross, form the imposing Cross Group complex. Together these three buildings constitute a triadic ritual complex in which each temple was dedicated to one of the three patron gods of Palenque (Stuart and Stuart 2008:189-211). The terminal phase of construction for these structures dates from A.D. 692, during the reign of K'inich Kan Bahlam II (Martin and Grube 2008:169; Stuart and Stuart 2008:193). Two further examples of polydactyly imagery have been identified on the panels adorning the jambs in the interior ritual sanctuary of the Temple of the Sun (Figure 11e and 11f). On these panels, it is the feet of the individuals depicted that appear to exhibit polydactyly, especially on the North Jamb (the details of the South Jamb have been affected by weathering). Here the individual rendered on the jamb is undoubtedly K'inich 
Kan Bahlam II, in the guise of a warrior, but no evidence of polydactyly of the hands is visible. The panels from the Temple of the Sun are at odds with other depictions of K'inich Kan Bahlam II, because nowhere else is he clearly rendered with polydactyly of the feet. It is noteworthy, however, that the Temple of the Sun was dedicated to the cult of Unen K'awiil, suggesting that there may have been a connection between polydactyly and this deity that has heretofore been overlooked.

\section{DISCUSSION}

Because the affected metatarsal from Peligroso was part of a cluster of disarticulated remains within a tomb, much of the contextual information about the individual has been lost. Analysis of other bones within the Peligroso tomb and from within the tombs of the other sites in the Upper Macal River Valley region revealed no further evidence of polydactyly, nor of any other symptoms suggestive of a related syndrome. Furthermore, no other archaeological examples have been reported from the Maya region or from other culture areas of Mesoamerica.

This lack of evidence might be considered curious because polydactyly is considered "common" in the clinical literature-usually one or two per 3,000 live births (although its occurrence in some ethnic groups has been estimated to be as high as 13.5 per 1,000 births) (Woolf and Myrianthopouloos 1973:400). Unfortunately, there have been no studies of polydactyly in modern Maya groups; this type of research could aid in reconstructing populationspecific patterns of expression and inheritance. The closest such study is Bingle and Niswander's (1975) survey of 44,149 Native North American infants, of whom 105 (.24\%) manifested some form of polydactyly. Numerous factors might explain its elusiveness in the archaeological record of Mesoamerica. The most obvious is the generally poor preservation of skeletal remains in the Maya region, making recovery and observation of smaller elements difficult. In addition, polydactyly may not always be easy to identify. As mentioned earlier, the expression of polydactyly ranges from a small "skin tag" without bones to a complete duplication of a digit. Because of generally poor preservation in the Maya region, smaller bones of the hands and feet are often not preserved, and thus most of the milder forms, which involve very small accessory bones, would not be identified or documented. Although Bingle and Niswander (1975:Table 1) report that the overall frequency of polydactyly in their study population of Native Americans was .24\%, the majority of these cases were Postaxial Type B, which would not be detectable archaeologically because of the absence of skeletal involvement. Furthermore, because of the common occurrence of multiple commingled burials both in tombs and in contexts with consecutive intrusive burials, individuals possessing the upper range of expression involving completely formed digits would have extra bones, which would more likely be attributed to an earlier, disturbed burial than recognized as polydactyly. In this latter case, it is very important to note the presence and location of extra bones during excavation.

For these reasons, the most likely form of polydactyly to be identified is that of the bifurcated digit or attached ray, like the Peligroso example and all other reported archaeological cases. These factors might contribute to the under-recognition of polydactyly in archaeological contexts. Moreover, as discussed above, there are several other genetic and environmental factors that further confuse and limit the use of polydactyly as a means of detecting biological relationships between individuals. These factors might also have played a role in the specific interpretation of polydactyly in ancient societies. As a result of the trait's relative rarity, as well as the obfuscation of its underlying mundane familial nature, incidences of polydactyly would have appeared sporadic and exotic, thus contributing to its interpretation, in some cultures, as divine.

As our review suggests, polydactyly appears to have been considered a supernatural trait by the Maya, suggesting that an individual with such an anomaly might have received special, perhaps even deferential, attention. In sum, the polydactyly seen on the piers of the Temple of the Inscriptions at Palenque may connect to the supernatural entity Unen K'awiil and thereby relate to the Mesoamerican pattern seen for the Zapotec and Teotihuacano cultures, in which divinities and deified ancestors are rendered with supernumerary digits. Of particular interest is the fact that the few known Maya iconographic depictions seem to symbolize the postmortem deification of individuals rather than antemortem representations of their actual physiology. The polydactyly rendered on the pier of House A has variously been attributed to either K' inich Kan Bahlam II or to his father, K'inich Janaab Pakal I. Because the remains of K'inich Janaab Pakal I have been the subject of recent osteological analyses (Romano 2006; Tiesler and Cucina 2006) it is clear that this individual was not affected by polydactyly of the hands, as implied by the iconography. Consequently, another individual might have been represented on the pier of House A, although it seems unwarranted to think that it should be K'inich Kan Bahlam II because no other depiction is known in which he exhibits polydactyly of the hands. The possibility thus emerges that House A provides a posthumous depiction, in which case the polydactyly might have conveyed that the individual assumed the status of deified ancestor. This leaves the examples of K'inich Kan Bahlam II in the Temple of the Sun. These may well dovetail with similar precepts, not the least because the structure in question was dedicated to Unen K'awiil, and renditions of the king with supernatural attributes might have fostered his connection to the patron deities, which he is said to have "cherished" (Stuart and Stuart 2008:191). There is every reason to suspect that K'inich Kan Bahlam II is buried in one of the temples of the Cross Group (Schele and Miller 1986:74, Note 4). Until the discovery and excavation of his tomb, however, it will remain impossible to examine the skeleton of K'inich Kan Bahlam II and to determine whether he was indeed affected by polydactyly, or whether a different explanation will find stronger footing to account for the iconographic renditions of polydactyly at Palenque.

Finally, different lines of indirect evidence of polydactyly taken from clinical studies of modern Native American groups (Bingle and Niswander 1975), from skeletal examples at archaeological sites in the American Southwest (Case et al. 2006) and Peru (Valerie Andrushko, personal communication 2010), and from the iconography reviewed above, together strongly suggest that some individuals in pre-Hispanic Mesoamerica did in fact exhibit polydactyly; the current study provides the heretofore missing direct evidence and thus affords the first opportunity to determine how this supernatural attribute might have affected the life of such an individual. Surprisingly, there appears to have been no real attempt to distinguish this individual. He or she was placed within an elaborately furnished tomb, suggesting elite status, but there is no evidence that the status was associated with the polydactyly. The mortuary context is typical of many Maya tombs in that it had been subsequently re-entered and the bones commingled. Maya collective tombs have most often been attributed to noble houses (Weiss-Krejci 2004), and such commingling within tombs is 
consistent with corporate group behavior of families in which an individual's specific social persona is subsumed within the larger group. As suggested by our review of inheritance patterns and frequency, the absence of any other cases within the tomb or other sites in the area is not particularly surprising, and does not imply that this individual was unrelated to these other individuals.

\section{CONCLUSIONS}

The metatarsal found within the Peligroso tomb represents the first skeletal evidence of polydactyly in Mesoamerica and thus offers a unique opportunity to evaluate the social significance of polydactyly in Classic period Maya society. Several iconographic depictions of polydactyly have been noted at the site of Palenque, and though these are either limited to postmortem representations of individuals or a means of accentuating relations to particular supernatural entities, the deliberate rendition of extra digits on individuals of high status substantiates the assertion that this condition was imbued with special significance. The presence of extra digits in Maya imagery may be a symbolic device marking the assumption of individuals to supernatural status, rather than the actual condition of the individuals' morphologies, following general patterns seen among the other few known Mesoamerican examples in which polydactyly can be equated with supernatural beings. The extra digit of the Peligroso individual would not have been large or aligned with the other digits such as those depicted at Palenque, and may not have even supported phalanges, so it is certainly possible that the protuberance may not have been recognized as anything more than an uncomfortable bump. However, it would undoubtedly have been visible, potentially marking the individual as "different" at birth. Thus, it is perhaps surprising that the remains of the Peligroso individual were included within a tomb of commingled remains. Nor is there any evidence that this individual was singled out as a result of this unusual and presumably significant trait. Although the elaborate tomb does suggest status and affluence, the individual was given no visible special or individualized treatment and thus might not have enjoyed distinction in life.

\section{RESUMEN}

Entre los restos humanos de la Tumba 1 del sitio Peligroso, Belice se descubrió un único quinto metatarso derecho, que exhibió una deformidad pequeña en forma de un pequeño $(7 \mathrm{~mm})$ dígito accesorio que emana de la mitad de la superficie plantar de la caña del hueso. La forma de la anomalía se afilia con el tipo A de polidactilia postaxial, lo que hace que este hallazgo sea el primer ejemplo arqueológico de polidactilia reportado de Mesoamérica. La polidactilia es un trastorno relativamente común y a menudo se transmite en familias y, por consiguiente, a pesar de que es un rasgo inusual, habría sido suficientemente común para exigir explicación. También se presenta un examen de idiomas indígenas americanos pertinentes como un medio para explorar las maneras por las cuales se conceptualizan los dígitos y el cuerpo humano. Representaciones iconográficas de polidactilia en el sitio maya de Palenque tienen paralelismos con otras representaciones mesoamericanas de dígitos supernumerarios que identifican divinidades y antepasados deificados, y así el rasgo parece que ha sido interpretado de manera particular y relativamente positiva. Sin embargo, el contexto funerario del ejemplo del sitio Peligroso representado por huesos desarticulados y mezclados, sugiere que el individuo no fue tratado de manera única y no tenía un distintivo papel social en base de la presencia de un dígito adicional.

\section{ACKNOWLEDGMENTS}

We are indebted for help and assistance to Rafael Guerra, Douglas Weinberg, Myka Schwanke, Sherry Gibbs, Troy Case, Rami I. Calis (Department of Orthopaedics, Emory University and Healthcare), Brooke White, the Belize Institute of Archaeology, The University of Mississippi Student Health
Services, and the University of Mississippi Department of Sociology and Anthropology. We would also like to thank Valerie Andrushko, Jesper Nielsen, Michael Spence, Rebecca Storey, and one anonymous reviewer for their insightful comments that have greatly improved this paper.

\section{REFERENCES}

Awe, Jaime J., Douglas M. Weinberg, and Rafael A. Guerra

2005 Belize Valley Archaeological Reconnaissance Macal River Project Archaeological Mitigation in the Upper Macal Valley: Report of Investigations Conducted between June-December 2003 and January-March 2004. Report submitted to the Belize Institute of Archaeology and the Belize Electric Company Limited, Belmopan. Unpublished manuscript on file, Institute of Arhcaeology, Belmopan, Belize.

Barnes, Ethne

1994 Polydactyly in the Southwest. Kiva 59:419-431.

Becker, Marshall J.

1971 The Identification of a Second Plaza Plan at Tikal, Guatemala, and its Implications for Ancient Maya Social Complexity. Unpublished Ph.D. dissertation. Department of Anthropology, University of Pennsylvania, Philadelphia.

1999 Excavation in Residential Areas of Tikal: Groups with Shrines, Tikal Report 21. University of Pennsylvania Museum of Archaeology and Anthropology, University of Pennsylvania, Philadelphia.

Bingle, Glenn J., and Jerry D. Niswander

1975 Polydactyly in the American Indian. American Journal of Human Genetics 27:91-99.
Campbell, Lyle

1979 Middle American Languages. In The Languages of Native North America: Historical and Comparative Assessment, edited by Lyle Campbell and Marianne Mithun, pp. 902-1000. University of Texas Press, Austin.

2004 Historical Linguistics: An Introduction. Edinburgh University Press, Edinburgh.

Campbell, Lyle, Terrence Kaufman, and Thomas C. Smith-Stark

1986 Meso-America as a Linguistic Area. Language 62:530-570.

Case, D. Troy, R. J. Hill, Charles F. Merbs, and Michael Fong

2006 Polydactyly in the Prehistoric American Southwest. International Journal of Osteoarchaeology 16:221-235.

Castilla, Eduardo, Regina Lugarihho da Fonseca, Maria da Graça Dutra, Eva Bermejo, Lourdes Cueva, and María Luisa Martínez-Frías

1996 Epidemiological Analysis of Rare Polydactylys. American Journal of Medical Genetics 65:295-303.

Castilla, Eduardo, Joaquín Paz, Osvaldo Mutchinick, Elsa Muñoz, Elba

Giorgiutti, and Zulema Gelman

1973 Polydactyly: A Genetic Study in South America. American Journal of Human Genetics 25:405-412. 
Chase, Arlen F., and Diane Z. Chase

1994 Maya Veneration of the Dead at Caracol, Belize. In Seventh Mesa Redonda de Palenque, 1989, Vol. VIII, edited by Merle G. Robertson and Virginia M. Fields, pp. 55-62. Pre-Columbian Art Research Institute, San Francisco.

Chase, Diane Z.

1994 Human Osteology, Pathology, and Demography as Represented in the Burials of Caracol, Belize. In Studies in the Archaeology of Caracol, Belize, edited by Diane Z. Chase and Arlen F. Chase, pp. 123-138. Pre-Columbian Art Research Institute, Monograph No. 7, San Francisco.

Christensen, Alexander F.

1998 Skeletal Evidence for Familial Interments in the Valley of Oaxaca, Mexico. Homo 49:273-288.

Christensen, Jeffery C., Fred B. Leff, Gary M. Lepow, Robert I. Schwartz,

Paul A. Colon, Steven T. Arminio, Peck Nixon, David Segel, and Stuart Leff

1981 Congenital Polydactyly and Polymetatarsalia: Classification, Genetics, and Surgical Correction. Journal of Foot Surgery 20:151-158.

Colas, Pierre Robert

2009 Deities of Transition: Death Gods among the Classic Maya. In The Maya and their Sacred Narratives: Text and Context in Maya Mythologies, edited by Geneviève Le Fort, Raphaël Gardiol, Sebastian Matteo, and Christophe Helmke, pp. 197-205. Acta Mesoamericana Vol. 20. Verlag Anton Saurwein, Markt Schwaben, Berlin.

Due, Berete

2007 Amerika. In Etnografisk Samling, edited by Christian Gulløv, Joan Hornby, and Espen Wæhle, pp. 8-41. Nationalmuseet, Copenhagen.

Feitosa, Mary F., Eduardo E. Castilla, Maria da Graça Dutra, and Henrique Krieger

1998 Lack of Evidence of a Major Gene Acting on Postaxial Polydactyly in South America. American Journal of Medical Genetics 80:466-472.

Gifford, James C.

1976 Prehistoric Pottery Analysis and the Ceramics of Barton Ramie in the Belize Valley. Memoirs of the Peabody Museum of Archaeology and Ethnology, Vol. 18. Harvard University, Cambridge.

Guenter, Stanley

2007 The Tomb of K'inich Janaab Pakal: The Temple of the Inscriptions at Palenque. Mesoweb. Electronic document, www. mesoweb.com/articles/guenter/TI.pdf, accessed February, 2010.

Han, Toni L., Sara L. Collins, Stephan D. Clark, and Anne Garland

1986 Moe Kaи a Ho'oilo: Hawaiian Mortuary Practices at Kēppu, Kōna, Hawai'i. Departmental Report Series No. 86-1. Bernice Pauahi Bishop Museum, Honolulu.

Haspelmath, Martin, Matthew S. Dryer, David Gil, and Bernard Comrie (editors)

2005 World Atlas of Language Structures. Oxford University Press, Oxford.

Hauser, Gertrud, and Gian Franco De Stefano

1989 Epigenetic Variants of the Human Skull. E. Schweizerbart'sche Verlagsbuchhandlung, Stuttgart.

Healy, Paul F., Jaime J. Awe, and Hermann Helmuth

1998 An Ancient Maya Multiple Burial at Caledonia, Cayo District, Belize. Journal of Field Archaeology 25:261-274.

Houston, Stephen D.

1992 A Name Glyph for Classic Maya Dwarfs. In The Maya Vase Book, Vol. 3, edited by Justin Kerr, pp. 526-531. Kerr Associates, New York.

Houston, Stephen, David Stuart, and Karl Taube

2006 The Memory of Bones: Body, Being, and Experience among the Classic Maya. University of Texas Press, Austin.

Jackson, A. T.

1938 Picture-Writing of Texas Indians. University of Texas Press, Austin.

Kaufman, Terrence

2003 A Preliminary Mayan Etymological Dictionary. Foundation for the Advancement of Mesoamerican Studies, Inc. Electronic document, http://www.famsi.org/reports/01051/pmed.pdf, accessed March, 2010.

Karttunen, Francis

1983 An Analytical Dictionary of Nahuatl. University of Texas Press, Austin.

Kuckelman, Kristin A., and Debra L. Martin

2007 Human Skeletal Remains. In The Archaeology of Sand Canyon Pueblo: Intensive Excavations at a Late-Thirteenth-Century Village in Southwestern Colorado, edited by Kristin A. Kuckelman. Crow
Canyon Archaeological Center. Electronic document, http://www. crowcanyon.org/sandcanyon, accessed March, 2010.

Lane, Rebecca A., and Audrey J. Sublett

1972 Osteology of Social Organization: Residence Patterns. American Antiquity 37:186-201.

Laughlin, Robert M.

1975 The Great Tzotzil Dictionary of San Lorenzo Zinacantán. Smithsonian Contributions to Anthropology, No. 19. Smithsonian Institution Press, Washington, DC.

Maas, Sarah A., and John F. Fallon

2005 Single Base Pair Change in the Long-Range Sonic hedgehog Limb-Specific Enhancer is a Genetic Basis for Preaxial Polydactyly. Developmental Dynamics 232:345-348.

Martin, Simon, and Nikolai Grube

2008 Chronicle of the Maya Kings and Queens: Deciphering the Dynasties of the Ancient Maya. 2nd ed. Thames and Hudson, London.

Martínez-Frías, María Luisa, Eva Bermejo, and Ana Cereijo

1992 Preaxial Polydactyly of Feet in Infants of Diabetic Mothers: Epidemiological Test of a Clinical Hypothesis. American Journal of Medical Genetics 42:643-646.

Miller, Virginia E.

1985 Dwarf Motif in Classic Maya Art. In Fourth Palenque Round Table, 1980, edited by Elizabeth P. Benson, pp. 141-154. Pre-Columbian Art Research Institute, San Francisco.

Miller, Mary, and Karl Taube

1993 An Illustrated Dictionary of the Gods and Symbols of Ancient Mexico and the Maya. Thames and Hudson, London.

Murphy, Kimmarie A.

1999 A Prehistoric Example of Polydactyly From the Iron Age Site of Simbusenga, Zambia. American Journal of Physical Anthropology 108:311-319.

Murphey, Mark D., James J. Choi, Mark J. Kransdorf, Donald J. Flemming, and Frances H. Gannon

2000 Imaging of Osteochondroma: Variants and Complications with Radiologic-Pathologic Correlation. Radiographics 20:1407-1434.

Ochoa Castillo, Patricia, and Federica Sodi Miranda (editors)

2009 Catalogue des œuvres exposées. Teotihuacan: Cité des Dieux, edited by Clémentine, Petit, Sophie, Trompette, Muriel, Rausch, and Sophie Chambonniére, pp. 204-471. Musée du quai Branly and Somogny éditions d'art, Paris.

Phelps, Dennis A., and Dennis P. Grogan

1985 Polydactyly of the Foot. Journal of Pediatric Orthopedics 5: 446-451.

Prager, Christian

2001 Court Dwarfs, the Companions of Rulers and Envoys of the Underworld. In Maya: Divine Kings of the Rainforest, edited by Nikolai Grube, Eva Eggebrecht, and Matthias Seidel, pp. 278-279. Könemann, Cologne.

Radhakrishna, Uppala, Asha S. Multani, Jitendra V. Solanki, Vinod C. Shah, and Niloufer J. Chinoy

1993 Polydactyly: A Study of a Five Generation Indian Family. Journal of Medical Genetics 30:296-299.

Reed, Erik K.

1981 Human Skeletal Material. In Contributions to Gran Quivira Archaeology, edited by Alden C. Hayes, pp. 75-118. Publications in Archeology No. 17. National Park Service, Washington, DC.

Regan, Marcia H., Christie G. Turner II, and Joel Irish

1996 Physical Anthropology of the Schoolhouse Point Mound, U:824/

13a. In The Place of the Storehouses: Roosevelt Platform Mound Study. Report on the Schoolhouse Point Mound, Pinto Creek Complex, Part 2, edited by Owen Lindauer, pp. 787-840. Anthropological Field Studies No. 35. Office of Cultural Resource Management, Department of Anthropology, Arizona State University, Tempe.

Robertson, Merle G.

1985 The Sculpture of Palenque, Volume III: The Late Buildings of the Palace. Princeton University Press, Princeton.

1991 The Sculpture of Palenque, Volume IV: The Cross Group, the North Group, the Olvidado, and Other Pieces. Princeton University Press, Princeton.

Robertson, Merle G., Marjorie S. Rosenblum Scandizzo, and John R.

Scandizzo

1976 Physical Deformities in the Ruling Lineage of Palenque, and the Dynastic Implications. In The Art, Iconography \& Dynastic History 
of Palenque, Part III, edited by Merle Greene Robertson, pp. 59-86. Robert Louis Stevenson School, Pebble Beach, CA.

Rodríguez Villegas, Manuel

2009a Diccionario español-yaqui. Aulex. Electronic document, http:// aulex.ohui.net/, accessed March, 2010.

2009b Diccionario español-kiliwa. Aulex. Electronic document, http://aulex.ohui.net/, accessed September, 2010.

Romano, Arturo

2006 Did Pakal Suffer from Deforming Diseases? True Facts and Iconographic Myths. In Janaab' Pakal of Palenque: Reconstructing the Life and Death of a Maya Ruler, edited by Vera Tiesler and Andrea Cucina, pp. 84-90. University of Arizona Press, Tucson.

Ruby, Leonard, and Michael J. Goldberg

1976 Syndactyly and Polydactyly. Orthopedic Clinics of North America 7:361-374.

Schele, Linda, and David Freidel

1990 A Forest of Kings: The Untold Story of the Ancient Maya. Quill and William Morrow, New York.

Schele, Linda, and Mary E. Miller

1986 The Blood of Kings: Dynasty and Ritual in Maya Art. George Braziller Inc. and the Kimbell Art Museum, New York and Fort Worth.

Sellen, Adam T.

2007 El cielo compartido: Deidades y ancestros en las vasijas efigie zapotecas. Centro Peninsular en Humanidades y Ciencias Sociales, Universidad Nacional Autónoma de México, Mexico City.

Smith-Stark, Thomas C.

1994 Mesoamerican Calques. In Investigaciones lingüisticas en Mesoamérica, edited by Carolyn J. MacKay, and Verónica Vázquez, pp. 15-50. Universidad Nacional Autónoma de México, Mexico City.

Stuart, David

1997 Kinship Terms in Maya Inscriptions. The Language of Maya Hieroglyphs, edited by Martha Macri and Anabel Ford, pp. 77-88. Pre-Columbian Art Research Institute, San Francisco.

Stuart, David, and George Stuart

2008 Palenque: Eternal City of the Maya. Thames and Hudson, New York.

Talamillo, Ana, María F. Bastida, Marian Fernández-Terán, and María A. Ros

2005 The Developing Limb and the Control of the Number of Digits. Clinical Genetics 67:143-153.
Thompson, Laurence C.

1979 Salishan and the Northwest. In The Languages of Native North America: Historical and Comparative Assessment, edited by Lyle Campbell and Marianne Mithun, pp. 692-765. University of Texas Press, Austin.

Tiesler, Vera, and Andrea Cucina (editors)

2006 Janaab' Pakal of Palenque: Reconstructing the Life and Death of a Maya Ruler. University of Arizona Press, Tucson.

Trumbull, J. Hammond

1874 On Numerals in American Indian Languages, and the Indian Mode of Counting. From the Transactions of the American Philological Association, 1874. American Philological Association, Hartford.

Venn-Watson, Edward A.

1976 Problems in Polydactyly of the Foot. Orthopedic Clinics of North America 7:909-927.

Vogt, Evon Z.

1976 Tortillas for the Gods: A Symbolic Analysis of Zinacanteco Rituals. Harvard University Press, Cambridge.

von Schuler-Schömig, Immina

1970 Figurengefässe aus Oaxaca, Mexico. Veröffentlichungen des Museums für Völkerkunde Berlin, No. 20. Staatliche Museen Preussischer Kulturbesitz, Museum für Völkerkunde, Berlin.

Walker, J.T.

1961 A Pedigree of Extra-Digit-V Polydactyly in a Batutsi Family. Annals of Human Genetics 25:65-68.

Watanabe, Hiroyuki, Shinya Fujita, and Ichiro Oka

1992 Polydactyly of the Foot: An Analysis of 265 Cases and a Morphological Classification. Plastic and Reconstructive Surgery 89: 856-877.

Weiss-Krejci, Estella

2004 Mortuary Representations of the Noble House: A Cross-cultural Comparison between Collective Tombs of the Ancient Maya and Dynastic Europe. Journal of Social Archaeology 4:368-404.

Welsh, W. Bruce M.

1988 An Anlaysis of Classic Lowland Maya Burials. BAR International Series 409. British Archaeological Reports, Oxford.

Woolf, Charles M., and Ntinos C. Myrianthopouloos

1973 Polydactyly in American Negroes and Whites. American Journal of Human Genetics 25:397-404.

Woolf, Charles M., and Robert M. Woolf

1970 A Genetic Study of Polydactyly in Utah. Human Genetics 22: 75-88. 